\title{
Study on Some Issues of International SMEs Promotion Policy
}

\author{
Munkherdene Tuvshintugs* \\ ${ }^{1}$ Mongolian National University of Commerce and Business, \\ Trade and Marketing Department, Ph.D Candidate of Jilin University in China \\ Tungalag Jargalsaikhan \\ ${ }^{2}$ Mongolian National University of Commerce and Business, \\ Trade and Marketing Department, Ass. Prof, Ph.D \\ Kone Abdrahamane \\ University of Social Sciences and Management of Bamako \\ Faculty of Economics and Managment Prof, Ph.D
}

\begin{abstract}
Now a day, we consider that development of a country is often determined by the development of its domestic production, especially small and medium enterprises. Therefore, this study aims to examine how countries are implementing policies to develop small and medium enterprises and how they are developing and implementing government support programs. The study looked at government support tools for SMEs in Mongolia, Japan, the United States, China, and Kazakhstan.
\end{abstract}

Keywords: SMEs, Promotion policy, International rules, discounted loans, financial support, management support DOI: $10.7176 / \mathrm{EJBM} / 13-3-13$

Publication date: January $31^{\text {st }} 2021$

\section{INTRODUCTION}

The role of small and medium-sized enterprises (SMEs) in the development process is very important not only in developing countries but also in developed countries. The development of SMEs is seen as accelerating the achievement of wider socio-economic objectives including poverty alleviation. Nowadays, entrepreneurship and firm creation is mostly related to small and micro firms, which lead us to look at them as an important development agent in any society. The development of proper policies addressed to promote SME and their behaviour to enhance SV faces two challenges: First of all, there is some controversy in the Academy for establishing proper performance indicators to measure SV creation (Ho Kang, Lee, and Huh 2010; Weerawardena and Mort 2006). For an effective supply-side support, it is essential to investigate the drivers of SMEs' performance (Ndiaye N., Razak L.A., Nagayev R. \& Ng A.,2018)

In the long run, profits are necessary for survival in a competitive business environment, but SME management may adopt grow or not to grow options. Long-term profitability derives from the relations between cost and revenue; which is a necessary but not sufficient condition for growth. While growth has been considered to be the most crucial measure in SME's, it has also been argued that sound financial performance is multidimensional in nature and that measures such as financial performance and growth are diverse aspects of performance that need to be considered (Wiklund, 1999). It has been argued that firms grow in many and that a firm's growth pattern is related to age, size and industry (Delmar, Davidsson, \& Gartner, 2003). The contributions of small and medium-sized enterprises (SMEs) to employment, output, and income in most economies is now undisputed (Robert B., David S, 2011)

Revenues may be held up by (Togtohbayar Lhagvasuren \& Huo Xuehuin, 2014): Analysis of the returns of small and medium-sized enterprises in Mongolia entry barriers such as competitive pricing and costs pushed down by management ingenuity. In a 'life-style' SME, an owner may trade profitability today against profitability tomorrow. Dynamic pricing or sequential investment projects may require initially lower profits in order to obtain higher future pay-offs from greater market penetration. An SME manager's time preference is likely to determine the inter-temporal profit trade-off. Profitability is among the most crucial objectives of financial management because the main goal of financial management is the maximization of the owner's wealth (McMahon \& Patton, 1995). Hence the success or failure of SMEs, or any other business establishment for that matter, heavily relies on the realization of profits. In the business cycle, a business is not usually profitable in the birth/establishment stage because this is the period of absorbing the costs emanating from the initial heavy capital outlay.

Recognising the importance of SMEs in economic development, the development in Mongolia has set up various programmes and institutions aimed at developing SME sector. Despite the contribution of SMEs to the economy, they are vulnerable and very few manage to survive due to challenging factors such as finance, a lack of business plans, high taxation, a lack of business management skills, low sales, low profitability, the high costs of doing business, labour market barriers, poor market condition, high rental charges, and wrong pricing. 
There are 94 thousand enterprises registered in Mongolia as of now, but 94942 of them conduct the business actively. As the statistical news, small and middle enterprises and businesses cover the $38.6 \%$ of total national products of our country, $38.2 \%$ of sales, $18.9 \%$ of official income taxes paid by the enterprises and organizations to the state budget and $21.8 \%$ of official trade taxes. $31 \%$ of 39 thousand small and middle enterprises conduct their businesses in the food sector, $16 \%$ of them engage in agriculture, $1 \%$ of them engage in sewing, $5.2 \%$ of them engage in skin, $5.1 \%$ of them conduct the wood processing business, $2 \%$ of them conduct the handcrafts and other present of them conduct the activities in the mining, energy, electronic, social, cultural and educational and medical sector.

The Mongolian government's SME policy established and created guidelines and framework to support them by implementing "Small and Medium-sized Enterprises Law" in 2007. "Small and medium-sized industrial equipment exemption from customs duties and VAT Law" in 2009, "Credit Guarantee fund" in 2012, the law is enforced. As well asstablishing Small and Medium Enterprises, an agency of the Government in 2008, implementing "Small and Medium Enterprise Development Program" in 2009, the government has been working to support small and medium enterprise development.

Small and medium enterprise business has been in the beginning of development. In order to develop that, it is significant to study unique of Traditional nomadic classic enterprise, traditional consumption of people and religions from the history.

There are 20195 enterprises registered in the local areas, but 14070 enterprises conduct the business stably. For the locations of small and middle enterprises, $70 \%$ of total enterprises conduct the activities in the settlement centers, including Ulaanbaatar, Darkhan and Erdenet city. 53627 enterprises are registered in Ulaanbaatar which is the Capital city of Mongolia as of December 2014, but 26851 of them conduct the business stably. 89.1 of these enterprises have $1-9$ workers, $4.8 \%$ of them have $10-19$ workers, $3.5 \%$ of them have $20-49$ workers and $2.6 \%$ of them have more than 50 workers.

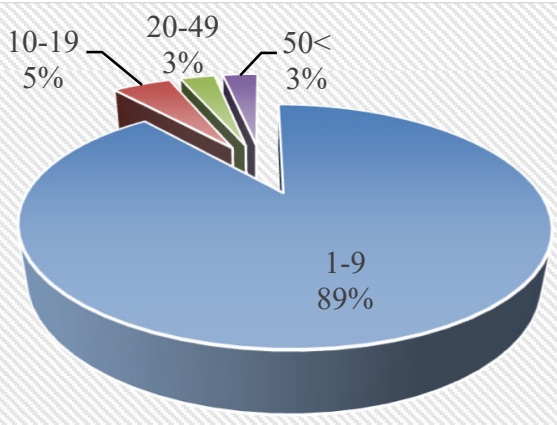

Figure 1. Business classification of small and middle enterprises /by number of workers/ Source: ubstat.mn/statistics

$0.2 \%$ of enterprises which are registered in Mongolia and $62.4 \%$ of enterprises which conduct the activities stably are located in Ulaanbaatar. $2.4 \%$ of enterprises which are registered in Ulaanbaatar are stated-owned stock companies, $0.1 \%$ of them are local-owned stock companies and $97.5 \%$ or 44263 of them are private companies. $4.8 \%$ of private companies are foreign incorporated companies and $6.6 \%$ of them are property of foreign citizen.

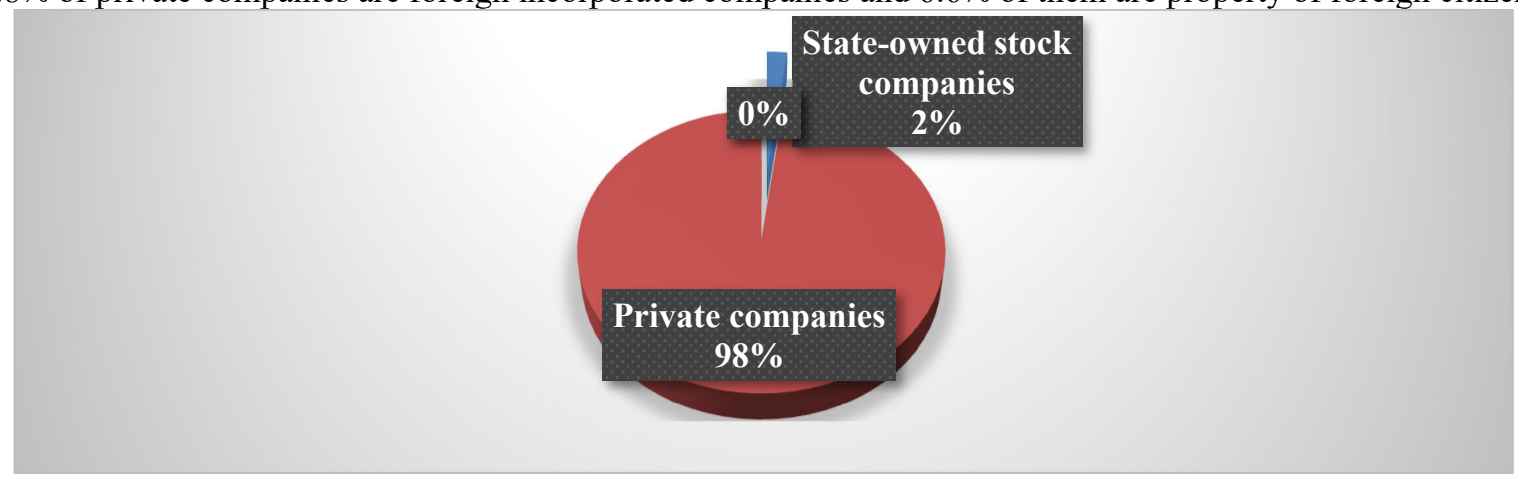

Figure 2. Ownership types of small and middle enterprises

Source: ubstat.mn/statistics

As the districts of enterprises which conduct the activities in Ulaanbaatar, the most small and middle enterprises are located in Bayangol and Bayanzurkh district.

The Government of Mongolia cooperates with Ministry of Finance, Central Bank of Mongolia and commercial banks in order to provide the long-term and low-interest loan resources for small and middle 
enterprises and increase the loan issues.

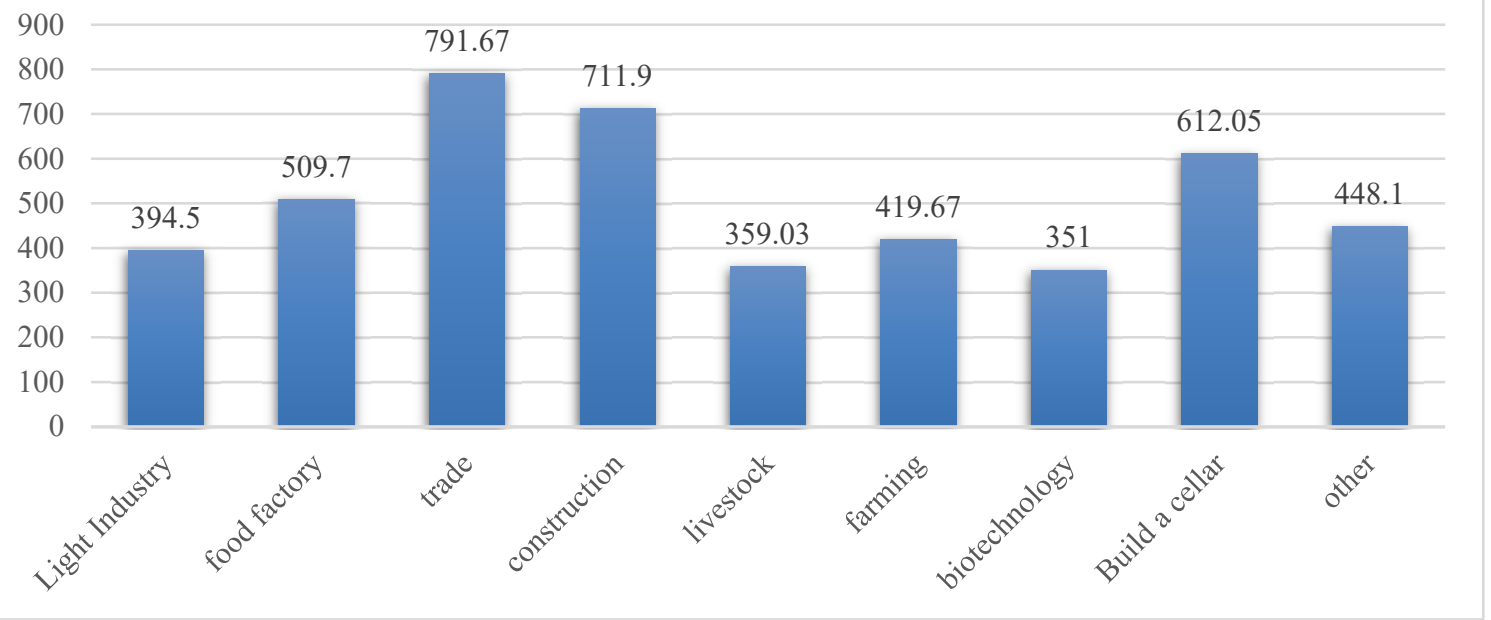

Source: ubstat.mn/statistics

Figure 3. Average of discounted loan

\section{METHODOLOGY AND INTERNATIONAL STUDY OF SMES}

We have studied the following countries based on some reason for good economic partnership with Mongolia, geographical proximity, and similar economic development.

Japan. The phrase "small and medium sized enterprises" started to be commonly used in Japan after the Meiji era (1868-1912) (Sato 1989). In those days there was no definition of a SME and the idea was vague; it meant that the size of a company was "relatively" small in comparison with other companies. In 1963, the government enacted the Small and Medium-sized Enterprise Basic Act, and a definition of SME was legally determined (Nakagawa, Rika. (2012) Accounting for $99.7 \%$ of all companies, $70 \%$ of all employees, and more than $50 \%$ of all added value (manufacturing industry) in Japan, SMEs form the very basis of the Japanese economy.

SME policies in Japan have been modified to adjust to changing economic conditions. SME policies during the 1980s were noteworthy for three reasons. First, they tried to encourage R\&D in SMEs, rather than the diffusion of existing technology. Second, the government recognized the positive effects of technology exchange and tieups among SMEs in different industries and began to encourage these activities. During the recession in the 1970s, SMEs in the machinery industry collaborated to produce high value-added products. The collaboration was effective for the joint development of unit components. Thus, in 1981, the government started technology exchange plaza projects to facilitate exchange and tie-ups among SMEs in each prefecture. In 1988, the government began to subsidize and give tax concessions to new technology developments by cooperative associations among SMEs in different industries. Third, the government encouraged new project ideas. Prefectural and municipal governments and the private sector got together and set up business incubators to reactivate local economies negatively affected by the recession. Subsidies from the government and low-interest loans from government financial institutions were provided to incubator projects. However, the occupation ratio of incubator projects was low due to the high rents. Such high rents were charged because prefectural and municipal governments gave priority to the acquisition of subsidies from the central government over careful examination of the feasibility of projects (Kurose \& Ross, 2006). Government had high expectations about the role of the RFC, which became a core institution for SME support in the country (Kiyonari 2009, p.2).

Table 1. Major SME-related Laws

\begin{tabular}{|l|c|}
\hline \multicolumn{1}{|c|}{ Name of Law } & Originally enacted \\
\hline Small Business Credit Insurance Law [Act No.264] & 1950 \\
\hline Small Business Finance Corporation Law [Act No.138] & 1953 \\
\hline SME Financial Assistance Law [Act No.115] & 1956 \\
\hline SMEs Association Organization Law [Act No.185] & 1957 \\
\hline Law Regarding Mutual Relief for Worker Retirement in SMEs [Act No.160] & 1959 \\
\hline SME Basic Law [Act No.154] & 1963 \\
\hline SME Support Law [Act No.147] & 1963 \\
\hline SME Investment and Promotion Company Law [Act No.101] & 1966 \\
\hline Law on Ensuring Government Procurement and Contracts for SMEs [Act No.97] & 1970 \\
\hline Law on the Promotion of Subcontracting SMEs [Act No.145] & 1973 \\
\hline Small and Medium Retail Business Promotion Law [Act No.101] & \\
\hline
\end{tabular}




\begin{tabular}{|l|c|}
\hline \multicolumn{1}{|c|}{ Name of Law } & Originally enacted \\
\hline Law for Facilitating New Businesses of SMEs [Act No.18] & 1999 \\
\hline Law on Organization for SMEs and Regional Innovation, Japan [Act No.147] & 2002 \\
\hline $\begin{array}{l}\text { Law concerning the Enhancement of the Fundamental Technologies for SME Creativity } \\
\text { (SME Technological Advancement Law) [Act No. 33] }\end{array}$ & 2006 \\
\hline
\end{tabular}

Source: Own processing.

Mentioned in terms of legal framework, the first SME Basic Law was enacted in 1963 and subsequently revised in 1973, 1983 and 1999. This 1999 amendment relates to the shift of its basic policies from "rectifying disadvantages" to "promoting diverse and vigorous growth and development of independent SMEs."

The Government of Japan implements the following policies to support SMEs.

Table 2. Outlines of Major SME policies by the SMEA

\begin{tabular}{|c|c|c|}
\hline \multirow[t]{15}{*}{1} & \multicolumn{2}{|l|}{ Management Support } \\
\hline & Start-ups and ventures & $\begin{array}{l}\text { Assists those planning to start a business or venture owners trying to } \\
\text { improve their operations in financing and obtaining relevant information. }\end{array}$ \\
\hline & Business innovation & $\begin{array}{l}\text { Assists SMEs undergoing business innovation in financing, handling taxed } \\
\text { and cultivating }\end{array}$ \\
\hline & New collaboration & $\begin{array}{l}\text { markets. Supports collaboration among SMEs to enter new area of business } \\
\text { by providing subsidiaries, advice and financing assistance }\end{array}$ \\
\hline & Business revitalization & $\begin{array}{l}\text { Supports SMEs' efforts to revitalize their business through the SME } \\
\text { Revitalization Support }\end{array}$ \\
\hline & $\begin{array}{l}\text { Employment and human } \\
\text { resources }\end{array}$ & $\begin{array}{l}\text { Supports SME human resources development and resolution of business } \\
\text { challenges by implementing the Small and Medium Sized Enterprise } \\
\text { Consultants system, offering training and dispatching experts. }\end{array}$ \\
\hline & Globalization & $\begin{array}{l}\text { perts. Provides information and advice to help SMEs to mover production } \\
\text { overseas or find markets }\end{array}$ \\
\hline & $\begin{array}{l}\text { Trade practices and public } \\
\text { procurement }\end{array}$ & $\begin{array}{l}\text { Promotes fair subcontracting practices and the development of small and } \\
\text { medium sized subcontractors and thereby increases the opportunity for } \\
\text { SMEs to win contracts. }\end{array}$ \\
\hline & Business stability & $\begin{array}{l}\text { Assists SMEs in maintaining stable operations by supporting them for } \\
\text { bankruptcy, pandemic new influenza, and earthquakes and other natural } \\
\text { disasters, as well as by leading them to develop a business continuity plan. }\end{array}$ \\
\hline & Mutual aid system & $\begin{array}{l}\text { Helps small companies to prepare for business closing and retirement, and } \\
\text { SMEs to prepare for the bankruptcy of their major customers. }\end{array}$ \\
\hline & Small businesses & $\begin{array}{l}\text { Provides managerial and financial support to small businesses with } 20 \text { or } \\
\text { fewer employees ( } 5 \text { or fewer for those in the commerce or service sector). }\end{array}$ \\
\hline & $\begin{array}{l}\text { Small and medium } \\
\text { manufacturers }\end{array}$ & $\begin{array}{l}\text { Supports R\&D and human resources development at SMEs with key } \\
\text { manufacturing technologies. Selects } 300 \text { of Japanese Exciting Monozukuri } \\
\text { (Manufacturing) SMEs }\end{array}$ \\
\hline & $\begin{array}{l}\text { Technological innovation, } \\
\text { IT and energy efficiency }\end{array}$ & $\begin{array}{l}\text { Assists SMEs committed to technological development, IT utilization and } \\
\text { higher energy efficiency by providing subsidies, financial assistance and } \\
\text { relevant information. }\end{array}$ \\
\hline & Intellectual property & $\begin{array}{l}\text { Supports SMEs intellectual property strategies by implementing measures } \\
\text { to protect intellectual property and measures to combat damage caused by } \\
\text { counterfeiting. }\end{array}$ \\
\hline & SME Assistance Centers & $\begin{array}{l}\text { Dispatches experts to assist SMEs in addressing difficult or specialized } \\
\text { business challenges (e.g., launch of new operations, business succession) } \\
\text { and otherwise helps SMEs directly or via support institutions. }\end{array}$ \\
\hline \multirow[t]{3}{*}{2} & \multicolumn{2}{|l|}{ Financing support } \\
\hline & $\begin{array}{l}\text { Safety-net } \\
\text { program }\end{array}$ & $\begin{array}{l}\text { Supports SMEs whose business stability is threatened by external factors } \\
\text { (e.g., a major customer restricted operations or application for rehabilitation } \\
\text { procedures, the impact of a disaster, failure of the main bank) by making } \\
\text { additional credit guarantees available. }\end{array}$ \\
\hline & Safety-net loans & $\begin{array}{l}\text { Makes loans to SMEs temporarily facing cash-flow problems due to a } \\
\text { radical change in the business environment, the bankruptcy of a major } \\
\text { customer, or the streamlining of the main bank. }\end{array}$ \\
\hline
\end{tabular}




\begin{tabular}{|c|c|c|}
\hline \multirow[t]{5}{*}{3} & \multicolumn{2}{|l|}{ Fiscal Support } \\
\hline & Taxation & Gives information and advice on various tax measures to support SMEs. \\
\hline & Accounting & $\begin{array}{l}\text { Gives information and advice on SME accounting, which helps SMEs to } \\
\text { enhance their capability to analyze management, ensure financing and } \\
\text { increase order intake. }\end{array}$ \\
\hline & Companies Act & $\begin{array}{l}\text { Gives information and advice on the new Companies Act, which } \\
\text { additionally includes systems that bring significant benefits to SMEs, such } \\
\text { as the accounting adviser system. }\end{array}$ \\
\hline & Business succession & $\begin{array}{l}\text { Gives information and advice on measures to support SMEs' smooth } \\
\text { business succession. }\end{array}$ \\
\hline \multirow[t]{5}{*}{4} & \multicolumn{2}{|c|}{ Commerce and Regional Support } \\
\hline & Revitalization of commerce & $\begin{array}{l}\text { Supports efforts to improve the attractiveness of small and medium } \\
\text { merchants, shopping districts and city centers. }\end{array}$ \\
\hline & Regional industries & $\begin{array}{l}\text { Invigorates regional industries, such as locally based industries and } \\
\text { traditional handicrafts industries, by providing subsidies and low-interest } \\
\text { loans. }\end{array}$ \\
\hline & $\begin{array}{l}\text { Collaboration between } \\
\text { agriculture, commerce and } \\
\text { industry }\end{array}$ & $\begin{array}{l}\text { Comprehensively assists business activities conducted by organic } \\
\text { partnerships between } \text { SMEs and those engaged in } \\
\text { agriculture/forestry/fisheries through the effective use of their business } \\
\text { resources. }\end{array}$ \\
\hline & $\begin{array}{l}\text { "Meet and Experience } \\
\text { Regional Attractiveness" } \\
\text { campaign }\end{array}$ & Aggressively increases the publicity of attractive regional products. \\
\hline & (1) & Enterprise \\
\hline
\end{tabular}

Kazakhstan. The government of Kazakhstan recognizes that a prosperous SME sector is key to the country's sustainable and stable long-term economic growth. A number of government initiatives have been undertaken in recent years to address the barriers faced by SMEs. State programs, which include 'Business Roadmap 2020') $)^{1}$ provide the general SME support policy framework. The goal of the government's efforts is to diversify the production base and promote the development of the SME sector, with a particular focus on its expansion and diversification. (ADB, 2010)

There are many government agencies supporting SMEs in the country. The main government agencies supporting SMEs are the Kazyna Fund, DAMU (Entrepreneurship Development Fund) ${ }^{2}$ Center for Marketing and Analytical Research (CMAR), and National Innovation Fund (NIF).

\footnotetext{
${ }^{1}$ This is a new program for enterprise development in a post-crisis period. This program has three directions in its policy. They are to support new business initiatives, to improve the business sector and to support export-oriented industries

2 Small Enterprise Development Fund (SMEF) was changed to DAMU Entrepreneurship Development Fund in 2007. (http;/www.damu.kz/239)
} 


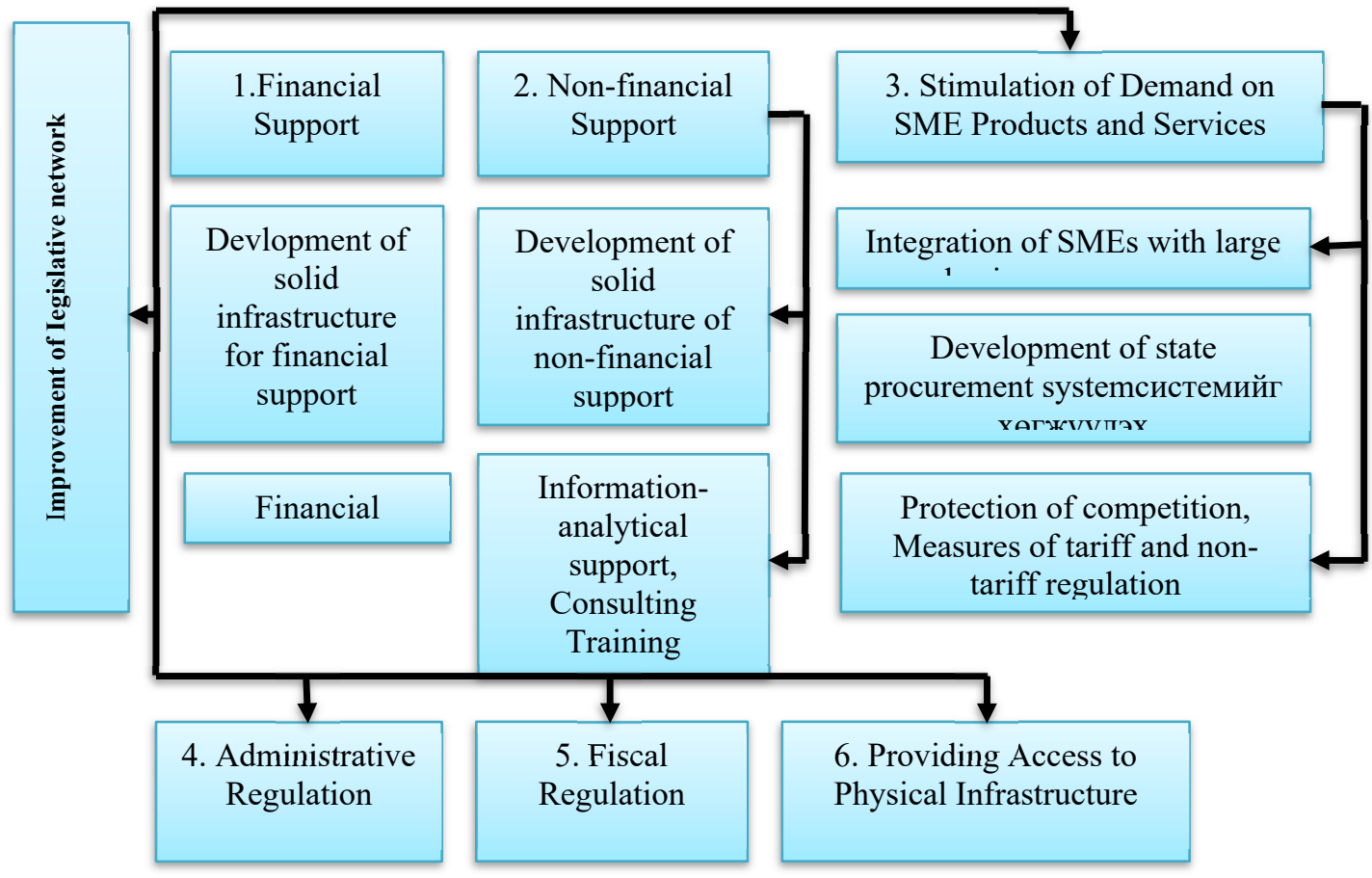

Source: DAMU

Figure 4. Government Support System for SMEs in Kazakhstan

As $<$ figure 4> shows, the government of Kazakhstan provides financial support and nonfinancial support through the organizations mentioned above.

USA. The US SME policy issue is raised by the Small Business Department, a government implementing agency. SME support policies typically include financial support, tax support, technical support, human resource support, and management support. This suggests that SMEs are a key driver of economic development. In concrete, their policy mainly consisted of financial support, taxation, technology, human resource, managerial support and so on.

SME Council

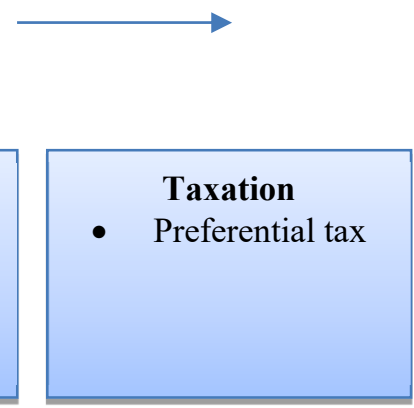

SME policy framework

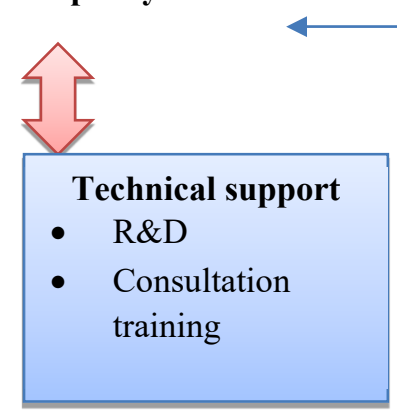

SME basic law

Figure 5. US SME Support Policy

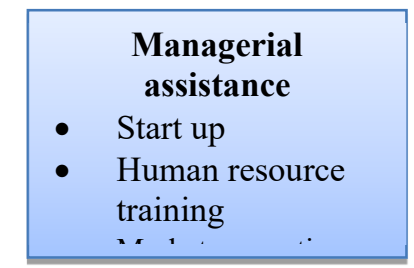

Manageria

Start up

Human resource training

There are four programmatic functions; access to capital, entrepreneurial development, government contracting, and advocacy. SBA provides small businesses with an array of financing for small businesses from the smallest needs in microlendng...to substantial debt and equity investment capital (venture capital). SBA provides free individual face-to face, and interest counseling for small businesses, and low-cost training to nascent entrepreneurs and established small businesses in over 1,800 locations throughout the United States and US territories.

Government contracting program ( Federal procurement) is Government contracting and SBIR program. Main role of SBIR (small business innovation \& small business technology transfer programs) is to promote federal high-tech programs to improve competitive capability of small business R\&D firms, to encourage state-ofthe-market technology training, technology information exchange, and outreach of federal technology programs.

China. During the last two decades, Chinese SMEs have been through three main development phases (Chen, 2006; Fornes et al., 2012). In the first phase (1978 to 1992), SMEs registered an important expansion and contributed to rapid economic and social development as a consequence of the government's support for the development of township, collective and self-employed enterprises (TVEs).The Chinese government has four divisions of the SME Development Policy Administration: the National Development and Innovation Committee, 
the SME Cooperation Coordination Center, the Chinese SME Association, and all provincial and local SME departments.

Table 3. Outlines of Major SME policies by the SMEA

\begin{tabular}{|c|c|c|}
\hline Year & Name & Summary \\
\hline $2003 \mathrm{NPC}^{1}$ & Law of SME Promotion & $\begin{array}{l}\text { Promotion through financial support, support for new } \\
\text { ventures, technological innovation, market development, } \\
\text { social service }\end{array}$ \\
\hline $2005 \mathrm{SC}^{2}$ & $\begin{array}{l}\text { Opinions on Encouraging \& } \\
\text { Guiding Development of } \\
\text { Individually Owned \& Private } \\
\text { Economy }\end{array}$ & $\begin{array}{l}\text { Entry permission, fiscal \& financial support \& social service } \\
\text { for private enterprises }\end{array}$ \\
\hline $2009 \mathrm{SC}$ & $\begin{array}{l}\text { Opinions on Further Promoting } \\
\text { SMEs }\end{array}$ & $\begin{array}{l}\text { Policy environment, financial \& fiscal policy, technology } \\
\text { renovation and structural reform, market \& management } \\
\text { development, public service }\end{array}$ \\
\hline $2010 \mathrm{SC}$ & $\begin{array}{l}\text { Opinions on Encouraging \& } \\
\text { Guiding the } \begin{array}{r}\text { Healthy } \\
\text { Development of } \\
\text { Investment }\end{array}\end{array}$ & $\begin{array}{l}\text { Entry of private investment into infrastructure, basic industry } \\
\text { (e.g. oil and telecom), public utility, public housing, social } \\
\text { service (e,g, medicine, education \& culture), finance, } \\
\text { commerce, defense. }\end{array}$ \\
\hline $\begin{array}{l}2011 \\
\text { MITT }^{3}\end{array}$ & Standard for SMEs & $\begin{array}{l}\text { Definition of SMEs in various industries which expand the } \\
\text { scope of small \& micro enterprise }\end{array}$ \\
\hline 2011 MITT & $\begin{array}{l}\text { The 12th } 5 \text { Year Plan for SME } \\
\text { Development }(2011-2015)\end{array}$ & $\begin{array}{l}\text { Achievement \& challenge. Objective \& main task, Key } \\
\text { project and measures for SME development 2011-2015 }\end{array}$ \\
\hline $2012 \mathrm{SC}$ & $\begin{array}{l}\text { Opinions on Further Supporting } \\
\text { Healthy Development of Small } \\
\text { \& Micro Enterprises }\end{array}$ & $\begin{array}{l}\text { Fiscal \& financial policy, technology renovation and } \\
\text { structural reform, market \& management development, } \\
\text { cluster development, public service, }\end{array}$ \\
\hline 2013 MITT & $\begin{array}{l}\text { Notice on Special Actions to } \\
\text { Assist Small \& Micro } \\
\text { Enterprises }\end{array}$ & $\begin{array}{l}\text { Objectives \& policies to promote small and micro enterprises } \\
\text { which are "new venture", "innovative" and "labor intensive" }\end{array}$ \\
\hline
\end{tabular}

Source: SC 2012 "Opinions on Further Supporting Healthy Development of Small \& Micro Enterprises"

Table 4. Outlines of Major SME policies by the SMEA

\begin{tabular}{|c|c|}
\hline Policy & Content \\
\hline Fiscal & $\begin{array}{l}\text { Enterprise Income Tax (EIT): } 20 \% \text { for SME, } 50 \% \text { of taxable income (firms income } \\
<30,000 \text { ) Increase the threshold of taxable revenue for business tax and VAT } \\
\text { - Special SME Funds } 14.1 \text { billion for } 2012 \\
\text { - SME Development Fund: } 15 \text { billion total in } 5 \text { years starting from } 2012 \text { Government } \\
\text { procurement: } 18 \% \text { for small \& micro enterprises } \\
\text { - } \text { Reduction of administrative fees for SMEs }\end{array}$ \\
\hline Financial & $\begin{array}{l}\text { - Monetary policy on growth and amount of loan to SMEs, and related reserve ratio, } \\
\text { - SPL } \\
\text { - Small financial institutions for small \& micro enterprises } \\
\text { "factoring" } \\
\text { - New collateral e.g. a/c receivable, shares, IP right, warehouse receipt, lease right } \\
\text { - Credit guarantee and insurance service for SMEs } \\
\text { - Standard on fees for financial service to SMEs }\end{array}$ \\
\hline $\begin{array}{l}\text { Innovation } \\
\text { Reform }\end{array}$ & $\begin{array}{l}\text { • Хувийн хэвшлийн хөрөнгө оруулалтыг өргөжүүлэх: Боловсрол, нийгмийн } \\
\text { халамж, технологи, аялал жуулчлал, худалдаа, эрчим хүч }\end{array}$ \\
\hline $\begin{array}{l}\text { Market } \\
\text { Development }\end{array}$ & $\begin{array}{l}\text { - Technical renovation for new materials, machines \& technology } \\
\text { - R\&D expense extra tax reduction, open R\&D facilities, IT application } \\
\text { - Creation, utilization, protection \& management of IT Technology incubator for new } \\
\text { ventures } \\
\text { - Expand areas for private investment: education, social welfare, technology, tourism \& } \\
\text { commerce } \\
\text { - Eliminate capacities with pollution, high energy \& resource consumption }\end{array}$ \\
\hline
\end{tabular}

\footnotetext{
${ }^{1}$ NPC: National People's Council

${ }^{2}$ SC: State Council

${ }^{3}$ MITT: Ministry of Industry \& Information Technology
} 


\begin{tabular}{|c|c|}
\hline Policy & Content \\
\hline $\begin{array}{l}\text { Management } \\
\text { Development }\end{array}$ & $\begin{array}{l}\text { - Encourage e-commerce, international exhibition \& Joint purchase and delivery } \\
\text { - Improve Customs passthrough connivence for SMEs } \\
\text { - Simplify procedure for selling in domestic market for export processing firms }\end{array}$ \\
\hline SME Clusters & $\begin{array}{l}\text { - Land \& rent subsidy for base of new venture, technology incubator, \& commercial } \\
\text { clusters } \\
\text { - Infrastructure \& service platform of technology, e-commerce, logistic \& information }\end{array}$ \\
\hline Public Service & $\begin{array}{l}\text { - Public service platform for policy enquiry, venture \& innovation, investment \& finance, } \\
\text { management clinic, IP, testing, HR, marketing, accounting, IT etc. } \\
\text { - Survey and monitoring of SMEs }\end{array}$ \\
\hline
\end{tabular}

The government is taking a number of steps to support SMEs. These include:

SME financing. State budget for SME financing to support SME development. It established a SME Development Fund to support tax incentives for SMEs.

Market access. The government helps SMEs improve their skills to improve market access. Access to the SME market is specifically supported by the country's industrial policy, industrial planning and regulations.

Enterprise network. The government supports eligible businesses to expand the network.

Effective SME management. The management characteristics of SMEs are working towards a better management system.

Social services to improve SMEs. The government is working to support brokerage institutions, support financing policies, provide training for business staff, strengthen new science and technology services, and establish a credit system to support businesses in foreign and domestic markets.

\section{CONCLUSION}

The role of small and medium-sized enterprises (SMEs) in the development process is very important not only in developing countries but also in developed countries. The development of SMEs is seen as accelerating the achievement of wider socio-economic objectives including poverty alleviation.

Firstly, the small and middle enterprises need to clear the difficulties of services of the state organizations, provide the discount and sufficient financial resources, provide the professional staffs and carry out the training, provide the good environment of taxation, provide the interest discount and implement news, information and technical issues at the policy level.

The news, information, technologies, consulting services and distant trainings about the small and middle enterprises through public media, including television, radio, newspaper and journal are the effective methods as well as sufficient to publics. Our country has the good taxation environment, but it can't influence to the small and middle enterprises positively. Also, the domestic total products are increased rapidly day by day, but the small and middle enterprises are not developed at the highest level. It shows that it is required of the taxation policy supporting them. For this, it is required to modify the official income taxes of enterprises and VAT which are the main taxes for small and middle enterprises.

The significances and influences of the small and middle enterprises to the society may be measured with the two basic criteria. They are numeral and non-numeral indexes, including total workplace numbers provided by the small and middle enterprises, working conditions of the workplace, salaries, export products, import replacement products and other conditions. Researchers of the world countries argue that determining numeral indexes or total workplace numbers provided by these enterprises is relatively easy, but studying the quality index or what condition and what salary does the small and middle businessman have is difficult.

The experience of the countries we studied shows that the governments commonly get attention to the professional advice is needed to improve the legal environment for SMEs, provide them with financial resources, upgrade equipment and technology, encourage experimentation and research initiatives, train and develop human resources, improve management capacity, provide consulting and assistance in working in foreign markets and the creation of a national brand.

\section{References}

\section{Journal article:}

Delmar, F., Davidsson, P., \& Gartner, W. (2003). Arriving at the high-growth firm. Journal of Business Venturing, $18,189-216$.

Kurose, J. F., \& Ross, K. W. (2006). Redes de Computadores e a Internet: uma abordagem top-down. 3.ed. Brazil, São Paulo: Person Addison Wesle.

McMahon, M., \& Patton, W. (1995). Development of a systems theory of career development. Australian Journal of Career Development, 4, 15-20.

Togtohbayar Lhagvasuren, \& Huo Xuehuin. (2014). Analysis of the returns of small and medium sized enterprises 
in Mongolia. Science Publishing Group.

Wiklund, J. (1999). The sustainability of the entrepreneurial orientation-Performance relationship. Entrepreneurship Theory and Practice, 24(1), 37-48.

Nelson Duarte (2004). "The role of smes for development: a literature review "regions and fiscal federalism"," ERSA conference papers ersa04p39, European Regional Science Association.

Ndiaye N., Razak L.A., Nagayev R. \& Ng A(2018) Demystifying Small and Medium Enterprises' (SMEs) Performance in Emerging and Developing Economies, Borsa istanbul Review Volume 18, Issue 4, December 2018, Pages 269-281

Nakagawa, Rika. (2012). The Policy Approach In Promoting Small And Medium Sized Enterprises In Japan. International Business \& Economics Research Journal (IBER). 11. 1087. 10.19030/iber.v11i10.7254.

Chen, J. (2006). "Development of Chinese Small and Medium-Sized Enterprises". Journal of Small Business and Enterprise Development, 13(2), 140-147.

Kiyonari, Tadao, The History of SMEs Policies in Japan (in Japanese, Nihon Chu-sho Kigyou Seisaku Shi), Yuhikaku, 2009.

Robert Blackburn, David Smallbone (2011) Policy support for SMEs, Environment and Planning C: Government and Policy 2011, volume 29, pages 571-576

Fornes, G., Cardoza, G., \& Xu, S. (2012). "The national and international expansion of Chinese SMEs: evidence from Anhui Province". Journal of Chinese Entrepreneurship, 4(3), 221-242.

Garrigos-Simon, Fernando \& González-Cruz, Tomás \& Contreras-Pacheco, Orlando. (2016). Policies to enhance social development through the promotion of SME and social entrepreneurship: a study in the Colombian construction industry. Entrepreneurship \& Regional Development. 1-20. 10.1080/08985626.2016.1255437.

Cooper, A. C. and F. J. Gimeno-Gascon (1992), 'Entrepreneurs, processes of founding and new firm performance'. In: D. Sexton and J. Kasarda (eds.): The State of the Art in Entrepreneurship. Boston, MA: PWS Publishing Co

Ganbaatar Khuyag, Lakshmi Boojoo, Tomoko Nishimoto, Deborah France-Massin "Formalizing enterprises in Mongolia: Challenges and policy directions.” MONEF, EPCRC, ROAP, ACT/EMP.

Tang, M. (2013). Facilitating SME: the Chinese Perspective. Mekong Forum 2013, KhonKaen,Thailand, pp. 4.

Tungalag.J, Ts.Gantsetseg,Ts. (2017). "Study on the some issues for state policy of SMEs in Mongolia",

\section{Books:}

Ariunkhishig,G."Results among small and medium-sized enterprises in poll”, 2012.

Ryan.J.D, Robert J.Gay, Gail P. Hiduke "Small business An entrepreneur plan", fifth edition, 1985.

Tsagaankhuu, Ts."Research of small and medium-sized enterprises in the capital", 2010.

\section{Reports:}

Development of small and medium-sized enterprises, bank of Mongolia, 2019

Ministry of Economic Development and Trade (MEDT), Republic of Kazakhstan. (2011) "SME-centered Enterprise Development Strategy for Sustained Economic Development of Kazakhstan"

Teruhiko Yoshimura, Rika Kato (2007) "The Policy Environment for Promoting SMEs in Japan"

Shuji Uchikawa (2009) "Small and Medium Enterprises in Japan: Surviving the Long-Term Recession" ADBI Working Paper Series

SME Small and medium enterprise development American's development foundation, 2010 year

SME owners manual, The Ministry of Labour, 2020 